\title{
Ekoblogy Maňa Huby
}

\section{Mikuláš Huba}

\section{Envigogika 8 (5) Informace/Information}

Publikováno/ Published 31. 12. 2013

DOI: http://dx.doi.org/10.14712/18023061.423

\section{Z webovej stránky Obyčajných ochranárov}

Milé čitatelky a milí čitatelia,

pri príležitosti blížiacej sa šest́desiatky mi napadlo zostavit' a vydat́ knižku 60 ekoblogov. Kedže nevýjde skôr, ako na budúci rok, oslovil som správcu nášho webu, Riša Medala, že bysme mohli každý týždeň jeden $z$ "ekoblogov" zavesit́ na náš web a tým upútat' Vašu pozornost' na to, čo chystáme.

Blogy vznikli v rokoch 2006 - 2011, teda v poslednom období pred mojím návratom do parlamentu.

Niektoré neboli dosial' publikované, niektoré publikované boli, ale v skrátenej či inak modifikovanej podobe.

Pre lepšiu orientáciu ich budeme čislovat' a uvádzat aj kapitolu, do ktorej budú v knižke zaradené.

O ilustrácie som požiadal d'alšieho takmer šest́desiatnika, Fera Guldana, takže texty občas spestria jeho nenapodobitel'né kresby.

Budem rád, ak týmto mojim krátkym textom venujete pár minút času a teším na Vaše prípadné ohlasy.

S pozdravom

Maňo Huba

\section{Posledné ekoblogy:}

Ekoblog č. 18 (kapitola Mesto): Neznesitel'ná krutost' dnešnej architektúry alebo Moje zhrozenie $z$ rodného mesta

Ekoblog č. 17 (kapitola Mesto): Bratislavské stromy po štvrt'storočí

Ekoblog č. 16 (kapitola Ochrana prírody): V Tatrách už stačilo kompromisov a ústupkov zo strany ochranárov a vedcov! 
Prof. RNDr. Mikuláš Huba CSc., geograf, krajinný ekológ a environmentalista, samostatný vedecký pracovník a zástupca riaditel'a Geografického ústavu SAV, člen Snemu SAV, ... Viacej $\underline{\text { tu}}$. 